\title{
Changes in the Profile and Care of HIV-HCV Seropositive Patients in Two Cross-Sectional Surveys in France (2006 and 2013)
}

Patrice Cacoub ${ }^{1-4}$, Arielle Elmaleh-Sachs ${ }^{1,4}$, Isabelle Poizot-Martin ${ }^{5}$, Cécile Goujard ${ }^{6}$, Patrick Miailhes ${ }^{7}$, Philippe Morlat ${ }^{8}$, Julie Chas $^{9}$, Isabelle Goderel ${ }^{10}$, Philippe Halfon ${ }^{11}$, François Caron ${ }^{12}$, David Rey ${ }^{13}$, François Boue ${ }^{14}$, Anne Simon ${ }^{15}$, Stanislas Pol ${ }^{16}$, Eric Rosenthal ${ }^{17}$ and The GERMIVIC Study Group ${ }^{18}$

${ }^{1}$ Sorbonne Universités, UPMC Univ Paris 06, UMR 7211, and Inflammation-Immunopathology-Biotherapy Department (DHU i2B), F-75005, Paris, France 2INSERM, UMR_S 959, F-75013, Paris, France

${ }^{3}$ NRS, FRE3632, F-75005, Paris, France

${ }^{4}$ AP-HP, Groupe Hospitalier Pitié-Salpêtrière, Department of Internal Medicine and Clinical Immunology, F-75013, Paris, France

${ }^{5}$ Service de Maladies Infectieuses, Hôpital Sainte Marguerite, Marseille, France

${ }^{6}$ Service de Médecine Interne, Hôpital du Kremlin Bicêtre, Le Kremlin Bicêtre, France

${ }^{7}$ Service de Maladies Infectieuses, Hôpital de La Croix Rousse, Lyon, France

${ }^{8}$ Service de Médecine Interne, Hôpital Saint André, Bordeaux, France

${ }^{9}$ Service de Maladies Infectieuses, Hôpital Tenon, Paris, France

10INSERM U707, Université Pierre et Marie Curie, Paris, France

${ }^{11}$ Service de Maladies Infectieuses, Hôpital Ambroise Paré, Marseille, France

${ }^{12}$ Service de Maladies Infectieuses, Hôpital Charles Nicolle, Rouen, France

${ }^{13}$ Service de Maladies Infectieuses, Hôpitaux Universitaires, Strasbourg, France

${ }^{14}$ Service de Médecine Interne, Hôpital Antoine Béclère, Clamart, France

${ }^{15}$ Service de Médecine Interne, Hôpital Pitié-Salpêtrière, Paris, France

${ }^{16}$ Service d'Hépatologie, Hôpital Cochin, Université René Descartes Paris V and INSERM U567, Paris, France ${ }^{17}$ Service de Médecine Interne, Hôpital de l'Archet, Nice, France

${ }^{18}$ GERMIVIC Study Group, France

*Corresponding author: Patrice Cacoub, Hôpital Pitié-Salpêtrière, Département de Médecine Interne et d'Immunologie Clinique, Paris, F-75013, France, Tel: 33142178027; Fax: 33142178033; E-mail: patrice.cacoub@psl.aphp.fr

Received date: September 22, 2014; Accepted date: November 24, 2014; Published date: November 28, 2014

Copyright: (c) 2014 Cacoub P, et al. This is an open-access article distributed under the terms of the Creative Commons Attribution License, which permits unrestricted use, distribution, and reproduction in any medium, provided the original author and source are credited.

\section{Abstract}

Aim: To analyze HCV care and treatment in HIV-HCV coinfected patients and their evolution between 2006 and 2013, in France.

Patients and methods: HIV-HCV consecutive seropositive patients were prospectively included in two crosssectional studies from April 3 to 10, $2006(n=416)$ and from April 8 to 15, $2013(n=342)$. A standard data collection form was used.

Results: Patients in 2013 compared to those in 2006 had undetectable HIV viral load and negative HCV viremia more often ( $82 \%$ vs. $69 \%$, and $48 \%$ vs. $27 \%$, respectively), with more frequent co-infection by HCV genotype 1 and 4. Liver biopsy was done less frequently ( $5 \%$ vs. $35 \%$ ). Non-invasive liver damage assessment was done more frequently ( $42 \%$ vs. $22 \%)$, using serum biomarkers ( $37 \%$ vs. $67 \%$ ) or liver-stiffness methods (69\% vs. $11 \%)$. A sustained virological response to HCV treatment was more frequent (50\% vs. 30\%). In both surveys, patients who had received HCV treatment compared to those who had never been treated were more often of European origin, had better control of their HIV infection, had more frequent liver damage assessments and were less frequently infected by a genotype 4 .

Conclusion: In comparison to 2006, more co-infected patients in 2013 had better control of their HIV infection, had liver damage assessment, received HCV treatment and more frequently had a sustained virological response. New anti-HCV combinations with greater efficacy and less toxicity should soon modify the present picture.

Keywords: HCV; HIV; HIV-HCV co-infection; Treatment

\section{Introduction}

About $30 \%$ of human immunodeficiency virus (HIV)-infected patients in France are also infected with hepatitis C virus (HCV), representing close to 30,000 patients [1-8]. Since the widespread use of highly active antiretroviral therapy (ART) began, AIDS mortality has progressively decreased, while chronic liver disease, linked primarily to $\mathrm{HCV}$, has emerged as one of the leading causes of morbidity and mortality in HIV-positive patients [2,5,7-10]. The combination of pegylated interferon and ribavirin produces sustained virological 
Citation: Cacoub P, Elmaleh-Sachs A, Poizot-Martin I, Goujard C, Miailhes P, et al. (2014) Changes in the Profile and Care of HIV-HCV Seropositive Patients in Two Cross-Sectional Surveys in France (2006 and 2013). J AIDS Clin Res 5: 388. doi: $10.4172 / 2155-6113.1000388$

Page 2 of 7

responses (SVR) in $27-44 \%$ of co-infected patients [11-14]. In early 2010, the HCV treatment "revolution" started using a combination of pegylated interferon, ribavirin and direct antiviral agents, i.e. first generation protease inhibitors, that increased SVR rates up to $75 \%$ in HCV genotype 1 mono-infection [15,16] and 74\% in co-infection [17], with a poor tolerance. And more recently, short, well-tolerated oral regimens, without interferon, have been effective in nearly $100 \%$ of patients in curing HCV infection [18,19].

HCV treatment, however, has only been given to a small number of HIV-HCV co-infected patients [20,21]. In a previous study in 2006, $42 \%$ of 393 HIV-HCV co-infected patients had never received HCV treatment [21]. Following the First European Consensus Conference on the treatment of chronic hepatitis B and C in HIV-infected patients in 2005, new recommendations have been given to optimize the care of HIV-HCV co-infected patients [22].

The aim of the present study was to analyse the profile and care of HIV-HCV co-infected patients in France in 2013 and to compare the results with those obtained in the 2006 survey.

\section{Patients and Methods}

The same methodology was used in the two surveys, and details have been published elsewhere [21]. Physicians involved in the management of HIV-infected patients were recruited from 50 specialized centres from all of metropolitan France participating in the GERMIVIC study group. Each physician was asked to prospectively fill out a standardized data collection form for all HIV-HCV coinfected patients seen between April 3 and 10, 2006 (2006 survey) and between April 8 and 15, 2013 (2013 survey). The form included sociodemographic data of the patient and physician, the HIV and HCV virological status, information regarding the pre-therapeutic workup of HCV infection, liver damage assessment (biopsy or non-invasive tests), the type of HCV treatment and its follow-up, and the use of erythropoietin or antidepressants. This form had been pre-tested by five physician specialists managing HIV-HCV co-infected patients in order to optimize the type and means of data collection.

\section{Results}

Fifty-eight and 34 physicians following HIV-HCV co-infected patients participated in the 2006 and 2013 studies, respectively. These physicians were from departments of infectious disease ( $50 \%$ vs. $56 \%$ ), internal medicine ( $44 \%$ vs. $40 \%$ ), or hepatogastroenterology (6\% vs. $4 \%)$.

During the weeks the studies were carried out, 416 and 342 HIVHCV co-infected patients were included in 2006 and 2013, respectively (Table 1); they were mainly of male gender and of European origin, with a mean age of 43.6 vs. 49.2 years. Most patients had been infected via drug use injection, although there was an increase of transmission via heterosexual ( $10 \%$ vs. $15 \%)$ and homosexual activity (6\% vs. $13 \%)$. The therapeutic management of HIV was already good in 2006 and it appeared to be even better in 2013, as evidenced by high rates of undetectable HIV viral load and CD4 levels $>350 / \mathrm{ml}$. Most patients received ART for their HIV infection ( $97 \%$ vs. $94 \%$ ), i.e. boosted protease inhibitor based ( $63 \%$ vs. $54 \%$ ), non-nucleoside based (18\% vs. $27 \%)$, or other regimen (19\% vs. 19\%). An excessive alcohol consumption (i.e. $>30 \mathrm{gr} / \mathrm{d}$ ) was noted in $145 / 412(35 \%)$ vs. $32 / 321$ (10\%) patients in the 2006 and 2013 survey, respectively. The rate of active IV drug users was 70/410 (17\%) vs. 48/319 (15\%).

\begin{tabular}{|c|c|c|c|c|c|c|c|c|c|c|c|}
\hline & \multicolumn{5}{|c|}{2006 survey } & \multicolumn{5}{|c|}{2013 survey } & \multirow[t]{3}{*}{$\mathbf{P}^{*}$} \\
\hline & \multicolumn{2}{|c|}{$\begin{array}{l}\text { Patients treated } \\
\text { for HCV infection }\end{array}$} & \multicolumn{2}{|c|}{$\begin{array}{l}\text { Patients NOT treated } \\
\text { for HCV infection }\end{array}$} & \multirow[b]{2}{*}{ Total (\%) } & \multicolumn{2}{|c|}{$\begin{array}{l}\text { Patients treated } \\
\text { for HCV infection }\end{array}$} & \multicolumn{2}{|c|}{$\begin{array}{l}\text { Patients NOT treated } \\
\text { for HCV infection }\end{array}$} & \multirow[b]{2}{*}{ Total (\%) } & \\
\hline & Number & $\%$ & Number & $\%$ & & Number & $\%$ & Number & $\%$ & & \\
\hline & & & & & 416 & & & & & 342 & \\
\hline Age mean, years & 43.6 & & 43.3 & & 43.6 & 49.5 & & 48.9 & & 49.2 & $<0.001$ \\
\hline \multicolumn{12}{|l|}{ Gender } \\
\hline Male & 163 & 74 & 109 & 67 & $272(71)$ & 140 & 70 & 81 & 66 & $221(68)$ & 0.46 \\
\hline Female & 58 & 26 & 53 & 33 & $111(29)$ & 63 & 30 & 42 & 34 & $105(32)$ & 0.27 \\
\hline \multicolumn{12}{|l|}{ Geographic origin } \\
\hline Europe & 188 & 85 & 122 & 75 & $310(81)$ & 139 & 81 & 79 & 77 & $218(80)$ & 0.52 \\
\hline Non Europe & 33 & & 41 & & $74(19)$ & 33 & 19 & 23 & 23 & $56(20)$ & 0.11 \\
\hline \multicolumn{12}{|c|}{ Mode of infection transmission } \\
\hline Injection drug use & 179 & 79 & 131 & 80 & $310(77)$ & 141 & 63 & 84 & 60 & $225(62)$ & 0.28 \\
\hline $\begin{array}{l}\text { Heterosexual } \\
\text { activity }\end{array}$ & 22 & 10 & 18 & 11 & $40(10)$ & 27 & 12 & 26 & 19 & $53(15)$ & 0.83 \\
\hline Homosexual activity & 19 & 8 & 7 & 4 & $26(6)$ & 30 & 13 & 16 & 12 & $46(13)$ & 0.60 \\
\hline Transfusion & 5 & 2 & 3 & 2 & $8(2)$ & 15 & 7 & 4 & 3 & $19(5)$ & 0.63 \\
\hline
\end{tabular}


Citation: Cacoub P, Elmaleh-Sachs A, Poizot-Martin I, Goujard C, Miailhes P, et al. (2014) Changes in the Profile and Care of HIV-HCV Seropositive Patients in Two Cross-Sectional Surveys in France (2006 and 2013). J AIDS Clin Res 5: 388. doi: $10.4172 / 2155-6113.1000388$

Page 3 of 7

\begin{tabular}{|c|c|c|c|c|c|c|c|c|c|c|c|}
\hline Hemophilia & 5 & 2 & - & - & $5(1)$ & 8 & 4 & 3 & 2 & $11(3)$ & 0.51 \\
\hline Unknown & 5 & 2 & 10 & 6 & $15(4)$ & 3 & 1 & 6 & 4 & $9(2)$ & 1.00 \\
\hline \multicolumn{12}{|l|}{ HIV viral load } \\
\hline Undetectable & 170 & 76 & 96 & 60 & $266(69)$ & 177 & 86 & 96 & 75 & $273(82)$ & 0.86 \\
\hline$<10^{5}$ copies $/ \mathrm{ml}$ & 36 & 16 & 34 & 21 & $70(18)$ & 23 & 11 & 25 & 20 & $48(14)$ & 0.85 \\
\hline $10^{5}-10^{6}$ copies $/ \mathrm{ml}$ & 15 & 7 & 26 & 16 & $41(11)$ & 5 & 2 & 7 & 5 & $12(4)$ & 0.75 \\
\hline$>10^{6}$ copies $/ \mathrm{ml}$ & 2 & 1 & 5 & 3 & $7(2)$ & 1 & 1 & 0 & 0 & $1(-)$ & 0.38 \\
\hline \multicolumn{12}{|l|}{$\mathrm{CD} 4 / \mathrm{ml}$} \\
\hline$<200$ & 16 & 7 & 33 & 20 & $49(13)$ & 18 & 8 & 19 & 15 & $37(11)$ & 0.18 \\
\hline $200-349$ & 69 & 31 & 46 & 28 & $115(30)$ & 37 & 18 & 27 & 21 & $64(19)$ & 0.87 \\
\hline $350-500$ & 70 & 32 & 40 & 25 & $110(29)$ & 39 & 19 & 25 & 19 & 64 (19) & 0.77 \\
\hline$>500$ & 66 & 30 & 44 & 27 & $110(28)$ & 116 & 55 & 58 & 45 & $174(51)$ & 0.26 \\
\hline
\end{tabular}

Table 1: Main demographic and HIV characteristics of HIV-HCV co-infected patients, in those who had received HCV treatment and those who had never been treated in the 2006 and 2013 surveys. ${ }^{*} \mathrm{P}$ corresponds to the comparison between 2006 and 2013 surveys.

Patients had been diagnosed with HCV infection for an average of 9.6 vs. 15.5 years. Patients in 2006 compared to those in 2013 had a positive HCV viremia more often [243/333 (73\%) vs. 165/317 (52\%)]. The distribution of HCV genotypes has changed from 2006 to 2013, i.e. genotype 1 from $50 \%$ to $59 \%$ and genotype 4 from $15 \%$ to $17 \%$ (Table 2). The pre-therapeutic HCV workup including a liver damage assessment by biopsy or non-invasive tests was done in about twothirds of patients in both surveys. However, the rate of "liver biopsy only" has strikingly decreased from $35 \%$ to $5 \%$ while the use of "non- invasive tests only" increased from $22 \%$ to $42 \%$. Non-invasive liver tests had been done using serum biomarkers in 124/185 (67\%) vs. $107 / 291$ (37\%), elastometry in 20/185 (11\%) vs. $199 / 298$ (69\%), or both in $41 / 185$ (22\%) vs. $73 / 291$ (25\%) patients in the 2006 and 2013 survey, respectively. The follow up of cirrhotic patients ( 99 vs. 76 patients) included liver ultrasound exam in $83 / 99(84 \%)$ vs. $66 / 76(87 \%)$, and upper digestive tract endoscopy in $83 / 99$ (84\%) vs. $29 / 76(38 \%)$ in the 2006 and 2013 survey, respectively. Only 8\% and 14\% patients had been sent for evaluation to a liver transplant unit.

\begin{tabular}{|c|c|c|c|c|c|c|c|c|c|c|c|}
\hline & \multicolumn{5}{|c|}{2006 survey } & \multicolumn{5}{|c|}{2013 survey } & \multirow{3}{*}{$\mathbf{P}^{*}$} \\
\hline & \multicolumn{2}{|c|}{$\begin{array}{l}\text { Patients treated for } \\
\text { HCV infection }\end{array}$} & \multicolumn{2}{|c|}{$\begin{array}{l}\text { Patients } \\
\text { treated for } \\
\text { infection }\end{array}$} & \multirow[t]{2}{*}{ Total (\%) } & \multicolumn{2}{|c|}{$\begin{array}{l}\text { Patients treated for } \mathrm{HCV} \\
\text { infection }\end{array}$} & \multicolumn{2}{|c|}{$\begin{array}{l}\text { Patients NOT treated for } \\
\text { HCV infection }\end{array}$} & \multirow[t]{2}{*}{ Total (\%) } & \\
\hline & Number & $\%$ & Number & $\%$ & & Number & $\%$ & Number & $\%$ & & \\
\hline \multicolumn{12}{|l|}{ HCV RNA copies/ml } \\
\hline Positive & 141 & - & 102 & - & 243 & 94 & - & 71 & - & 165 & 0.84 \\
\hline$<800,000$ & 64 & - & 53 & - & 117 & 37 & - & 30 & - & 67 & 1 \\
\hline$>800,000$ & 77 & - & 49 & - & 126 & 55 & - & 37 & - & 92 & 0.89 \\
\hline Negative & 64 & - & 26 & - & 90 & 104 & - & 48 & - & 152 & 0.77 \\
\hline Not done/missing & 17 & - & 33 & - & 40 & 12 & - & 11 & - & 23 & 0.2 \\
\hline \multicolumn{12}{|l|}{ HCV genotype } \\
\hline Genotype 1 & 105 & 49 & 66 & 50 & $171(50)$ & 116 & 60 & 44 & 56 & $160(59)$ & 0.036 \\
\hline Genotype 2 & 22 & 10 & 7 & 5 & $29(8)$ & 6 & 3 & 1 & 1 & $7(3)$ & 1 \\
\hline Genotype 3 & 61 & 29 & 32 & 24 & $93(27)$ & 35 & 18 & 19 & 24 & $54(20)$ & 1 \\
\hline Genotype 4 & 25 & 12 & 27 & 20 & $52(15)$ & 34 & 18 & 15 & 19 & $49(17)$ & 0.043 \\
\hline Genotype 5 & 0 & 0 & 0 & 0 & $0(0)$ & 1 & 1 & 0 & 0 & $1(1)$ & . \\
\hline
\end{tabular}


Citation: Cacoub P, Elmaleh-Sachs A, Poizot-Martin I, Goujard C, Miailhes P, et al. (2014) Changes in the Profile and Care of HIV-HCV Seropositive Patients in Two Cross-Sectional Surveys in France (2006 and 2013). J AIDS Clin Res 5: 388. doi: $10.4172 / 2155-6113.1000388$

Page 4 of 7

\begin{tabular}{|l|l|l|l|l|l|l|l|l|l|l|l|l|l|}
\hline Genotype 6 & 0 & 0 & 0 & 0 & $0(0)$ & 0 & 0 & 0 & 0 & 0 \\
\hline \\
Liver damage assessment \\
\begin{tabular}{|l|l|l|l|l|l|l|l|l|l|} 
Liver biopsy and/or \\
non invasive \\
markers
\end{tabular} & 213 & 100 & 112 & 100 & $325(78)$ & 175 & 100 & 78 & 100 & $253(74)$ & 0.37 \\
\hline Liver biopsy only & 106 & 47 & 41 & 25 & $147(35)$ & 14 & 8 & 4 & 5 & $18(5)$ & 0.78 \\
\hline $\begin{array}{l}\text { Non invasive } \\
\text { markers only }\end{array}$ & 40 & 18 & 53 & 32 & $93(22)$ & 87 & 50 & 57 & 73 & $144(42)$ & 0.011 \\
\hline Both & 67 & 30 & 18 & 11 & $85(20)$ & 73 & 42 & 16 & 21 & $89(26)$ & 0.7 \\
\hline None & 14 & 6 & 52 & 32 & $66(16)$ & 21 & 12 & 30 & 38 & $51(15)$ & 0.025 \\
\hline
\end{tabular}

Table 2: Main characteristics of HCV infection in HIV-HCV co-infected patients, in those who had received HCV treatment and those who had never been treated in the 2006 and 2013 surveys. ${ }^{*}$ P corresponds to the comparison between 2006 and 2013 surveys.

The analysis of HCV treatment showed patients, who had been previously treated or were receiving ongoing treatment represent $58 \%$ vs. $62 \%$ of the study populations in the 2006 and 2013 surveys, respectively (Table 3 ). There was no correlation between the rate of treated patients and HCV genotype distribution in both surveys. A sustained virological response to HCV treatment increased from $30 \%$ to $50 \%$; an absence of virological response was noted in $44 \%$ vs. $31 \%$, and a relapse or virological breakthrough in $26 \%$ vs. $19 \%$, respectively. In both surveys, most treated patients received a combination of pegylated interferon plus ribavirin while in the 2013 survey $12 \%$ of patients received a triple combination of pegylated interferon plus ribavirin plus protease inhibitor. Use of anti-depressant drug and erythropoietin decreased from the 2006 to 2013 survey.

\begin{tabular}{|c|c|c|c|c|c|}
\hline \multirow[t]{2}{*}{ Survey } & \multicolumn{2}{|l|}{2006} & \multicolumn{2}{|l|}{2013} & \multirow[t]{2}{*}{$\mathbf{P}$} \\
\hline & $\mathrm{N}=416$ & $\%$ & $\mathrm{~N}=342$ & $\%$ & \\
\hline \multicolumn{6}{|l|}{ Modalities of HCV treatment } \\
\hline Never treated & 164 & 42 & 130 & 38 & 0.71 \\
\hline Previously treated or ongoing treatment & 227 & 58 & 210 & 62 & 0.07 \\
\hline Unknown & 25 & - & 2 & - & $<0.001$ \\
\hline \multicolumn{6}{|l|}{ Modalities of the last HCV treatment } \\
\hline Peg-IFN plus ribavirin & 167 & 80 & 161 & 88 & 0.056 \\
\hline Peg-IFN plus ribavirin plus boceprevir & - & - & 11 & 6 & . \\
\hline Peg-IFN plus ribavirin plus telaprevir & - & - & 12 & 6 & . \\
\hline \multicolumn{6}{|l|}{ Virological response to HCV treatment } \\
\hline Sustained virological response & 50 & 30 & 80 & 50 & $<0.001$ \\
\hline Non virological response & 73 & 44 & 49 & 31 & 0.016 \\
\hline Virological relapse/breakthrough & 44 & 26 & 30 & 19 & 0.11 \\
\hline Missing & - & - & 34 & - & . \\
\hline Anti-depressant use & 77 & 20 & 8 & 2 & $<0.001$ \\
\hline Erythropoietin use & 27 & 7 & 16 & 5 & 0.34 \\
\hline
\end{tabular}

Table 3: Modalities and virological results of HCV treatment in HIV-HCV co-infected patients in the 2006 and 2013 surveys.

The rate of patients not treated for their $\mathrm{HCV}$ infection has decreased from 164/391 (42\%) to 130/340 (38\%) patients between 2006 and 2013 (Table 4). The main reasons given have changed: HCV treatment deemed questionable ( $44 \%$ vs. $24 \%$ ), contraindication to
HCV treatment (26\% vs. $11 \%)$ and patient refusal (21\% vs. $14 \%)$. In addition, in the more recent survey, $20 \%$ of patients were waiting for new HCV drugs. Where HCV treatment deemed questionable, the reasons given where: minimal hepatic lesions for $47 \%$ vs. $41 \%$, chronic 
Citation: Cacoub P, Elmaleh-Sachs A, Poizot-Martin I, Goujard C, Miailhes P, et al. (2014) Changes in the Profile and Care of HIV-HCV Seropositive Patients in Two Cross-Sectional Surveys in France (2006 and 2013). J AIDS Clin Res 5: 388. doi: $10.4172 / 2155-6113.1000388$

Page 5 of 7

excessive alcohol consumption for $29 \%$ vs. $7 \%$ and active drug use for $6 \%$ vs. $26 \%$ in the 2006 and 2013 survey, respectively.

\begin{tabular}{|c|c|c|c|c|c|}
\hline \multirow[t]{2}{*}{ Survey } & \multicolumn{2}{|l|}{2006} & \multicolumn{2}{|l|}{2013} & \multirow[t]{2}{*}{$\mathbf{P}$} \\
\hline & $\begin{array}{l}N \\
164 / 391\end{array}$ & $\begin{array}{l}\% \\
42\end{array}$ & $\begin{array}{l}N \\
130 / 340\end{array}$ & $\begin{array}{l}\% \\
38\end{array}$ & \\
\hline \multicolumn{6}{|l|}{ Main reason } \\
\hline $\begin{array}{l}\mathrm{HCV} \text { treatment deemed } \\
\text { questionable }\end{array}$ & 72 & 44 & 27 & 24 & $<0.001$ \\
\hline Absence of liver biopsy & 30 & 18 & 4 & 4 & $<0.001$ \\
\hline $\begin{array}{l}\text { Contraindication to } \mathrm{HCV} \\
\text { treatment }\end{array}$ & 43 & 26 & 13 & 11 & $<0.001$ \\
\hline $\begin{array}{l}\text { Physician conviction of non- } \\
\text { compliance with HCV treatment }\end{array}$ & 32 & 20 & 8 & 7 & 0.003 \\
\hline
\end{tabular}

\begin{tabular}{|l|l|l|l|l|l|}
\hline Patient refusal & 34 & 21 & 16 & 14 & 0.20 \\
\hline Waiting for new HCV drugs & - & - & 23 & 20 & - \\
\hline
\end{tabular}

Table 4: Main reasons for the non-treatment of HCV infection in HIV-HCV co-infected patients in the 2006 and 2013 surveys.

In comparison to non-treated patients in both surveys (Table 5), patients who had received HCV treatment were more likely to be of European origin, to have a better control of HIV infection, and to have had a liver damage assessment, whereas they were less frequently infected by a genotype 4 . When we compared 2006 and 2013 surveys for these parameters, two main differences appeared in the more recent survey i.e. treated patients had an even better control of HIV infection and had had very rarely had a liver biopsy.

\begin{tabular}{|l|l|l|l|l|l|l|}
\hline & \multicolumn{2}{|l|}{$\mathbf{2 0 0 6}$ survey } & 2013 survey & \multicolumn{2}{l|}{$\mathbf{p}$} \\
\hline & $\begin{array}{l}\text { Patients treated } \\
\mathbf{N}=\mathbf{1 6 3}\end{array}$ & $\begin{array}{l}\text { Patients NOT treated } \\
\mathbf{N}=\mathbf{2 5 3}\end{array}$ & $\begin{array}{l}\text { Patients treated } \\
\mathbf{N = 2 1 0}\end{array}$ & $\begin{array}{l}\text { Patients } \\
\text { treated } \\
\mathbf{N}=\mathbf{1 3 0}\end{array}$ & $\mathbf{N O T}$ & $\begin{array}{l}\mathbf{P} \begin{array}{c}\text { for } \\
\text { patients }\end{array} \\
\text { treated } \\
\mathbf{P} \text { for non-treated } \\
\text { patients }\end{array}$ \\
\hline $\begin{array}{l}\text { Geographic origin from } \\
\text { Europe }\end{array}$ & $85 \%$ & $75 \%$ & $81 \%$ & $78 \%$ & 0.33 & 0.61 \\
\hline $\begin{array}{l}\text { Undetectable HIV viral } \\
\text { load }\end{array}$ & $76 \%$ & $60 \%$ & $86 \%$ & $75 \%$ & 0.015 & 0.003 \\
\hline CD4/ml <200 & $7 \%$ & $20 \%$ & $9 \%$ & $15 \%$ & 0.44 & $<0.001$ \\
\hline Genotype 4 & $12 \%$ & $20 \%$ & $17 \%$ & $19 \%$ & 0.24 & 0.010 \\
\hline Liver biopsy & $47 \%$ & $25 \%$ & $7 \%$ & $4 \%$ & $<0.001$ & $<0.001$ \\
\hline
\end{tabular}

Table 5: Main differences in HIV-HCV co-infected patient, between those who had received HCV treatment and those who did not in the 2006 and 2013 surveys.

\section{Discussion}

The care of HIV-HCV co-infected patients has changed in France. In comparison to 2006, more co-infected patients in 2013 had better control of HIV infection, had liver damage assessment, received HCV treatment (that was less contraindicated) and showed higher sustained virological responses rates.

The present study shows that between 2006 and 2013, the percentage of co-infected patients who had never received $\mathrm{HCV}$ treatment decreased, probably because such treatment was less contraindicated. In a recent Swedish study, $75 \%$ of 652 HIV-HCV coinfected patients did not initiate HCV treatment [23]. In a large European analysis of 25 studies including 19,014 HCV patients, the mean rate of no treatment in HCV RNA-positive patients was $57 \%$ in the overall population, $64 \%$ in HIV-HCV co-infected patients and up to $72 \%$ in IV drug users [24]. Provider-level barriers include provider inexperience with antiviral treatment and/or reluctance of providers to refer patients for treatment. The potential difficulties of starting HCV treatment seemed to be reflected by the profile of never-treated patients, notably with HCV treatment being deemed questionable for the patient (excessive alcohol consumption and active drug use), physicians' conviction of poor future compliance (unfavorable socioeconomic conditions) or the presence of contraindications to $\mathrm{HCV}$ treatment [25,26]. In Europe, the predominant barriers to HCV treatment in co-infected patients are direct or indirect limitations of interferon-alfa and/or parenteral drug and alcohol abuse $[23,24,28]$. Fifty-three per cent of 200 co-infected patients had an absolute contraindication to interferon therapy, $61 \%$ of whom reported heavy drinking [27,28]. Data from the 2005-2010 U.S. National Hospital Ambulatory Medical Care Surveys showed that comorbidities varied across the subgroups with more current tobacco use $(40 \%, 27 \%, 30 \%)$ and depression $(32 \%, 23 \%, 24 \%)$ in the HIV$\mathrm{HCV}, \mathrm{HIV}$ and HCV subgroups, respectively [30]. Caring for patients who use illicit drugs presents challenges to the health care team that require patience, experience, and an understanding of the dynamics of substance use and addiction. Nonetheless, programs are successfully integrating hepatitis $\mathrm{C}$ care for IV drug users into health-care settings [29]. Patient-level barriers include non-adherence to medical care, refusal of therapy, and social circumstances [31,32]. In order to improve uptake of HCV therapy in persons with HIV-HCV coinfection, it is essential that barriers, both new and ongoing, are addressed through the institution of a therapeutic contract between physicians and patients. This would allow the reduction or termination of chronic alcohol consumption or better management of active drug use, knowing that these addictions no longer constitute an automatic barrier to treatment $[21,26,32,33]$. In light of newer HCV treatment options, greater efforts to remove the barriers to treatment 
Citation: Cacoub P, Elmaleh-Sachs A, Poizot-Martin I, Goujard C, Miailhes P, et al. (2014) Changes in the Profile and Care of HIV-HCV Seropositive Patients in Two Cross-Sectional Surveys in France (2006 and 2013). J AIDS Clin Res 5: 388. doi: $10.4172 / 2155-6113.1000388$

Page 6 of 7

that still exist for a great proportion of HIV-HCV co-infected patients should be undertaken. HIV infection per se does not appear as a main barrier to HCV treatment. The immuno-virological control of HIV infection was good in both surveys and even better in the 2013 vs. 2006 survey. Of note, the sub-group of patients who had received HCV treatment had an even better control of HIV infection in both surveys (Table 5).

In both surveys, the wider use of non-invasive markers allowed liver damage to be assessed in more than two third of patients. The use of non-invasive markers of liver fibrosis, either biochemical [34-36] or morphological (liver-stiffness methods) [36-38], allowed the degree of liver involvement in HIV-HCV co-infected patients to be easily assessed. A recent study of 435 liver biopsy pairs from $282 \mathrm{HIV}-$ HCV co-infected patients without cirrhosis showed that fibrosis progression was common and progression was rapid [39]. Liver stiffness method-based prediction can achieve a similar yield as liver biopsy-based models to predict overall mortality in HIV-HCV coinfected patients. Such models can predict better liver decompensations than liver biopsy [40]. Sustained clearance of serum HCV-RNA following a course of antiviral treatment is the major determinant of liver fibrosis regression in HIV-HCV coinfected patients [41]. An observational study of 216 HIV-HCV coinfected patients who received therapy against HCV and had at least three successive transient elastographies during the follow-up showed that the rate of liver fibrosis regression increased during the follow-up after SVR to interferon therapy [42].

The importance of multidisciplinary teams has been underlined for optimizing the management of HCV in co-infected patients $[21,26,43]$. In both surveys, most treated patients had received the best combination of pegylated interferon and ribavirin. A sustained virological response rate of 50\% was noted in the 2013 survey, a figure close to that obtained in other studies in co-infection [44] as well as in HCV mono-infection. Liver transplantation has been approached with caution in HIV-HCV co-infected patients with end-stage liver disease because of concern over the sequelae of immunosuppression and ART-related hepatotoxicity. Such patients, however, should be investigated early in a liver transplant unit where the appropriateness of transplantation will be discussed [45-47]. Several direct-acting antivirals have now entered clinical practice and others have reached advanced stages of clinical development. Treatments such as sofosbuvir have received approval for HIV-HCV co-infected patients $[48,49]$. The results of trials using direct-acting antivirals in coinfection showed that treatment response rates are similar to those obtained in HCV mono-infection. Moreover, interferon-free options exist for HIV-HCV co-infected patients who may be ineligible or intolerant of interferon [50]. Thus, HIV should no longer be considered as a "special" population, as long as anti-retroviral therapy is given and drug interactions are taken into account [51].

In conclusion, compared to 2006, more co-infected patients in 2013 had better control of their HIV infection, had liver damage assessment, received HCV treatment and more frequently had a sustained virological response. These results underline the importance of continuing efforts to increase the access of co-infected patients to HCV treatment. New anti-HCV combinations with greater efficacy and less toxicity should soon modify the present picture.

\section{Acknowledgment}

We thank you Merk Sharp Dohme for their support.

\section{References}

1. Cacoub P, Geffray L, Rosenthal E, Perronne C, Veyssier P, et al. (2001) Mortality among human immunodeficiency virus-infected patients with cirrhosis or hepatocellular carcinoma due to hepatitis C virus in French Departments of Internal Medicine/Infectious Diseases, in 1995 and 1997. Clin Infect Dis 32: 1207-1214.

2. Rosenthal E, Poirée M, Pradier C, Perronne C, Salmon-Ceron D, et al. (2003) Mortality due to hepatitis C-related liver disease in HIV-infected patients in France (Mortavic 2001 study). AIDS 17: 1803-1809.

3. Bica I, McGovern B, Dhar R, Stone D, McGowan K, et al. (2001) Increasing mortality due to end-stage liver disease in patients with human immunodeficiency virus infection. Clin Infect Dis 32: 492-497

4. Jaggy C, von Overbeck J, Ledergerber B, Schwarz C, Egger M, et al. (2003) Mortality in the Swiss HIV Cohort Study (SHCS) and the Swiss general population. Lancet 362: 877-878.

5. Tedaldi EM, Baker RK, Moorman AC, Alzola CF, Furhrer J, et al. (2003) Influence of coinfection with hepatitis $\mathrm{C}$ virus on morbidity and mortality due to human immunodeficiency virus infection in the era of highly active antiretroviral therapy. Clin Infect Dis 36: 363-367.

6. Lewden C, Salmon D, Morlat P, Bévilacqua S, Jougla E, et al. (2005) Causes of death among human immunodeficiency virus (HIV)-infected adults in the era of potent antiretroviral therapy: emerging role of hepatitis and cancers, persistent role of AIDS. Int J Epidemiol 34: 121-130.

7. Sherman KE, Rouster SD, Chung RT (2002) Hepatitis C virus prevalence among patients infected with human immunodeficiency virus: a crosssectional analysis of the US Adult AIDS Clinical Trials Group. Clin Infect Dis 34: 831-837

8. Rosenthal E, Pialoux G, Bernard N, Pradier C, Rey D, et al. (2006) Liverrelated mortality in human-immunodeficiency-virus-infected pa tients between 1995 and 2003 in the French GERMIVIC Joint Study Group (MORTAVIC 2003 Study). J Viral Hepat 14: 183-188

9. Cacoub P, Dabis F, Costagliola D, Almeida K, Lert F, et al. (2014) Burden of HIV and hepatitis C co-infection: the changing epidemiology of hepatitis $\mathrm{C}$ in HIV-infected patients in France. Liver Int .

10. Chung RT, Andersen J, Volberding P, Robbins GK, Liu T, et al. (2004) Peginterferon Alfa-2a plus ribavirin versus interferon alfa-2a plus ribavirin for chronic hepatitis C in HIV-coinfected persons. N Engl J Med 351: 451-459.

11. Torriani FJ, Rodriguez-Torres M, Rockstroh JK, Lissen E, GonzalezGarcía J, et al. (2004) Peginterferon Alfa-2a plus ribavirin for chronic hepatitis $\mathrm{C}$ virus infection in HIV-infected patients. N Engl J Med 351: 438-450.

12. Carrat F, Bani-Sadr F, Pol S, Rosenthal E, Lunel-Fabiani F, et al. (2004) A randomized controlled trial of pegylated interferon alfa- $2 \mathrm{~b}$ plus ribavirin versus standard interferon alfa- $2 \mathrm{~b}$ plus ribavirin for initial treatment of chronic hepatitis C in HIV-infected patients (RIBAVIC-ANRS HC02). JAMA 292: 2839-2848

13. Laguno M, Murillas J, Blanco JL, Martínez E, Miquel R, et al. (2004) Peginterferon alfa- $2 \mathrm{~b}$ plus ribavirin compared with interferon alfa- $2 \mathrm{~b}$ plus ribavirin for treatment of HIV/HCV co-infected patients. AIDS 18: F27-36.

14. Hézode C, Forestier N, Dusheiko G, Ferenci P, Pol S, et al. (2009) Telaprevir and peginterferon with or without ribavirin for chronic HCV infection. N Engl J Med 360: 1839-1850.

15. Poordad F, McCone J Jr, Bacon BR, Bruno S, Manns MP, et al. (2011) Boceprevir for untreated chronic HCV genotype 1 infection. N Engl J Med 364: 1195-1206.

16. Hézode C, Fontaine H2, Dorival C3, Zoulim F4, Larrey D5, et al. (2014) Effectiveness of telaprevir or boceprevir in treatment-experienced patients with HCV genotype 1 infection and cirrhosis. Gastroenterology 147: 132-142.

17. Sulkowski MS, Sherman KE, Dieterich DT, Bsharat M, Mahnke L, et al. (2013) Combination therapy with telaprevir for chronic hepatitis $C$ virus 
Citation: Cacoub P, Elmaleh-Sachs A, Poizot-Martin I, Goujard C, Miailhes P, et al. (2014) Changes in the Profile and Care of HIV-HCV Seropositive Patients in Two Cross-Sectional Surveys in France (2006 and 2013). J AIDS Clin Res 5: 388. doi: $10.4172 / 2155-6113.1000388$

Page 7 of 7

genotype 1 infection in patients with HIV: a randomized trial. Ann Intern Med 159: 86-96.

18. Jensen DM (2011) A new era of hepatitis C therapy begins. N Engl J Med 364: 1272-1274

19. Drenth JP (2013) HCV treatment--no more room for interferonologists? N Engl J Med 368: 1931-1932.

20. Cacoub P, Rosenthal E, Halfon P, Sene D, Perronne C, et al. (2006) Treatment of hepatitis $C$ virus and human immunodeficiency virus coinfection: from large trials to real life. J Viral Hepat 13: 678-682.

21. Cacoub P, Halfon P, Rosenthal E, Pialoux G, Benhamou Y, et al. (2008) Treatment of hepatitis $\mathrm{C}$ virus in human immunodeficiency virus infected patients in "real life": modifications in two large surveys between 2004 and 2006. J Hepatol 48: 35-42.

22. Alberti A, Clumeck N, Collins S, Gerlich W, Lundgren J, et al. (2005) Short statement of the first European Consensus Conference on the treatment of chronic hepatitis B and C in HIV co-infected patients. J Hepatol 42: 615-624.

23. Stenkvist J, Weiland O, Sönnerborg A, Blaxhult A, Falconer K (2014) High HCV treatment uptake in the Swedish HIV/HCV co-infected cohort. Scand J Infect Dis 46: 624-632.

24. Papatheodoridis GV, Tsochatzis E, Hardtke S, Wedemeyer H (2014) Barriers to care and treatment for patients with chronic viral hepatitis in Europe: a systematic review. Liver Int 34: 1452-1463.

25. Fleming CA, Craven DE, Thornton D, Tumilty S, Nunes D (2003) Hepatitis $C$ virus and human immunodeficiency virus coinfection in an urban population: low eligibility for interferon treatment. Clin Infect Dis 36: $97-100$.

26. Fleming CA, Tumilty S, Murray JE, Nunes D (2005) Challenges in the treatment of patients coinfected with HIV and hepatitis $\mathrm{C}$ virus: need for team care. Clin Infect Dis 40 Suppl 5: S349-354.

27. Cooper CL, Cameron DW (2005) Effect of alcohol use and highly active antiretroviral therapy on plasma levels of hepatitis C virus (HCV) in patients coinfected with HIV and HCV. Clin Infect Dis 41 Suppl 1: S105-109.

28. Nunes D, Saitz R, Libman H, Cheng DM, Vidaver J, et al. (2006) Barriers to treatment of hepatitis $\mathrm{C}$ in $\mathrm{HIV} / \mathrm{HCV}$-coinfected adults with alcohol problems. Alcohol Clin Exp Res 30: 1520-1526.

29. Johnson TL, Toliver JC, Mao L, Oramasionwu CU1 (2014) Differences in outpatient care and treatment utilization for patients with $\mathrm{HIV} / \mathrm{HCV}$ coinfection, HIV, and HCV monoinfection, a cross-sectional study. BMC Infect Dis 14: 217.

30. Edlin BR, Kresina TF, Raymond DB, Carden MR, Gourevitch MN, et al. (2005) Overcoming barriers to prevention, care, and treatment of hepatitis C in illicit drug users. Clin Infect Dis 40 Suppl 5: S276-285.

31. Oramasionwu CU, Moore HN, Toliver JC (2014) Barriers to hepatitis C antiviral therapy in HIV/HCV co-infected patients in the United States: a review. AIDS Patient Care STDS 28: 228-239.

32. Andersen KL, Larsen CS, Petersen MS, Leutscher PD (2014) Need for improvements in the surveillance and management of chronic viral hepatitis in HIV patients followed in a Danish outpatient clinic. Scand J Infect Dis 46: 578-584.

33. Fuster D, Tsui JI, Cheng DM, Quinn EK, Bridden C, et al. (2013) Impact of lifetime alcohol use on liver fibrosis in a population of HIV-infected patients with and without hepatitis C coinfection. Alcohol Clin Exp Res 37: 1527-1535.

34. Myers RP, Benhamou Y, Imbert-Bismut F, Thibault V, Bochet M, et al. (2003) Serum biochemical markers accurately predict liver fibrosis in HIV and hepatitis C virus co-infected patients. AIDS 17: 721-725.
35. Sterling RK, Lissen E, Clumeck N, Sola R, Correa MC, et al. (2006) Development of a simple noninvasive index to predict significant fibrosis in patients with HIV/HCV coinfection. Hepatology 43: 1317-1325.

36. Calès P, Halfon P, Batisse D, Carrat F, Perré P, et al. (2010) Comparison of liver fibrosis blood tests developed for HCV with new specific tests in HIV/HCV co-infection. J Hepatol 53: 238-244.

37. Castéra L, Vergniol J, Foucher J, Le Bail B, Chanteloup E, et al. (2005) Prospective comparison of transient elastography, Fibrotest, APRI, and liver biopsy for the assessment of fibrosis in chronic hepatitis C. Gastroenterology 128: 343-350.

38. Castera L, Winnock M, Pambrun E, Paradis V, Perez P, et al. (2014) Comparison of transient elastography (FibroScan), FibroTest, APRI and two algorithms combining these non-invasive tests for liver fibrosis staging in HIV/HCV coinfected patients: ANRS CO13 HEPAVIH and FIBROSTIC collaboration. HIV Med 15: 30-39.

39. Konerman MA, Mehta SH, Sutcliffe CG, Vu T, Higgins Y, et al. (2004) Fibrosis progression in human immunodeficiency virus/hepatitis $\mathrm{C}$ virus coinfected adults: prospective analysis of 435 liver biopsy pairs. Hepatology 59: 767-75.

40. Macías J, Camacho A, Von Wichmann MA, López-Cortés LF, Ortega E, et al. (2013) Liver stiffness measurement versus liver biopsy to predict survival and decompensations of cirrhosis among HIV/hepatitis C viruscoinfected patients. AIDS 27: 2541-2549.

41. Labarga P, Fernandez-Montero JV, Barreiro P, Pinilla J, Vispo E, et al (2014) Changes in liver fibrosis in $\mathrm{HIV} / \mathrm{HCV}$-coinfected patients following different outcomes with peginterferon plus ribavirin therapy. J Viral Hepat 21: 475-459.

42. Casado JL, Quereda C, Moreno A, Pérez-Elías MJ, Martí-Belda P, et al. (2013) Regression of liver fibrosis is progressive after sustained virological response to HCV therapy in patients with hepatitis $\mathrm{C}$ and HIV coinfection. J Viral Hepat 20: 829-837.

43. Clanon KA, Johannes Mueller J, Harank M (2005) Integrating treatment for hepatitis $\mathrm{C}$ virus infection into an HIV clinic. Clin Infect Dis 40 Suppl 5: S362-366.

44. Beisel C, Heuer M, Otto B, Jochum J, Schmiedel S, et al. (2014) German cohort of HCV mono-infected and HCV/HIV co-infected patients reveals relative under-treatment of co-infected patients. AIDS Res Ther 11: 16 .

45. Soriano V, Puoti M, Sulkowski M, Mauss S, Cacoub P, et al. (2004) Care of patients with hepatitis $C$ and HIV co-infection. AIDS 18: 1-12.

46. Neff GW, Shire NJ, Rudich SM (2005) Outcomes among patients with end-stage liver disease who are coinfected with HIV and hepatitis C virus. Clin Infect Dis 41: S50-55.

47. Antonini TM, Furlan V, Teicher E, Haim-Boukobza S, Sebagh M, et al. (2013) Successful anti-hepatitis C virus therapy with telaprevir in an $\mathrm{HIV} /$ hepatitis $\mathrm{C}$ virus co-infected patient with a severe recurrence of hepatitis C virus infection on the liver graft. AIDS 27: 2655-2657.

48. Sulkowski MS, Naggie S2, Lalezari J3, Fessel WJ4, Mounzer K5, et al. (2014) Sofosbuvir and ribavirin for hepatitis C in patients with HIV coinfection. JAMA 312: 353-361.

49. Cooper, Klein M (2014) HIV/hepatitis C virus coinfection management changing guidelines and changing paradigms. HIV Med 15: 621-624.

50. Sulkowski MS (2014) Interferon-containing and interferon-free HCV therapy for HIV-infected patients. Semin Liver Dis 34: 72-78.

51. Back D, Else L (2013) The importance of drug-drug interactions in the DAA era. Dig Liver Dis 45 Suppl 5: S343-348. 